http://dx.doi.org/10.7833/116-1-1298

\title{
BLACK THEOLOGY AND THE BLACK EXPERIENCE IN THE MIDST OF PAIN AND SUFFERING AMIDST POVERTY
}

Olehile A Buffel

Philosophy, Practical Theology and Systematic Theology

Unisa

\begin{abstract}
Despite promises of a 'better life for all' millions of mainly black South Africans are subjected to pain and suffering as a result of poverty. This calls for black theological reflection in the light of their experience and the Gospel. This also calls for prophetic activism similar to that provided by some leaders during the struggle for liberation, who unfortunately either joined 'party politics' or the civil service or are now focusing only on preaching that is unrelated to the pain and suffering of the poor. The article argues for pastors, theologians and lay leaders with strong organic links with the masses and their organisations to engage in prophetic activism.
\end{abstract}

Key Words:Black Theology; Black Experience; Pain, Suffering; Poverty; Prophetic Activism

\section{Introduction}

The article deals with Black Theology in the light of the black experience which involves pain and suffering as a result of poverty. When the new South Africa was ushered in, it promised a dream of better life for all, with the promises articulated by the ANC in its manifestoes, policies and political speeches. Long after political liberation, poverty, structural racism, inequality and unemployment are still rife, as economic liberation remains an illusion to millions of the poor. In the context of this dream that has been deferred, the church and its leadership have gone to sleep and are disturbingly silent in contrast to the past. This silence happens while many communities engage in service delivery protests, while the church and its leadership are nowhere to be seen. There is need for prophetic activism on the part of the clergy and theologians. They must have organic links with the masses if their theological reflections are to be relevant in the midst of pain and suffering. ${ }^{1}$ There is still need to engage in Black Liberation theology, despite efforts to build a nonracial society in South Africa, controversial and risky as this may sound.

\section{Black Theology: A Controversial Topic in Non-racial South Africa}

Writing about Black Theology has become a very controversial enterprise in a supposedly democratic and non-racial country, much as it was controversial to do theology during the era of apartheid. ${ }^{2}$ During that era Boesak argued that engaging in Liberation Theology was

Olehile Buffel, Black Theology and the Black Masses: The Need of an Organic Relationship between Black

Theology and the Black Masses, in Scriptura, 2010, 105:470.

2 Cf. Bonganjalo Goba, An Agenda for Black Theology. Johannesburg: Skotaville,1988, i. cf. Buffel, 470. 
an extremely difficult and risky business. ${ }^{3}$ This was due to the situation of extreme political repression which was characterised by torture, exile, detentions and death. ${ }^{4}$ Thanks to the establishment of a free and democratic South Africa, with one of the most 'progressive constitutions ${ }^{5}$ there been some positive changes. In that spirit President Nelson Mandela said at the time of his inauguration as the first president of a free, democratic and non-racial South Africa in 1994:

The moment to bridge the chasm that divides us has come ... we enter into a covenant that we shall build a society in which all South Africans, both black and white, will be able to walk tall without any fear in their hearts, assured of their inalienable right to human dignity - a rainbow nation which is at peace with itself and the world at large ... we must therefore act together as a united people for national recovery. Never, never and never again shall it be that this beautiful land will experience the oppression of one by another.

It therefore becomes controversial to write about Black Theology in a liberated, democratic and non-racial country. How do we write about Black Theology in the kind of country that Mandela and others envisaged and struggled for? Is that not an advocacy for racism in reverse? Does writing about anything black not make one liable to be accused of racism in reverse? The truth is that twenty-two years after liberation, South Africa is still a divided country, as acknowledged even by white academics and politicians such as Turok, Terreblache and others. ${ }^{7}$ The black ${ }^{8}$ experience is still different from the white experience. Blacks still live in parts that are predominantly black and whites live in parts that are predominantly white. Blacks still live in poverty and whites in wealth. ${ }^{9}$ The new South Africa, like the end of colonialism, did not bring about economic transformation in Africa as it did in Asia; if anything, it entrenched the economic inequalities inherited from colonialism. $^{10}$

We still have the dual economy, the first and the second economy which consists of a mixture of extreme wealth and power on the one hand and extreme poverty on the other. ${ }^{11}$ Extreme wealth is in the hands of whites and extreme poverty affects mainly blacks. A classic example of the existence of this dual economy and the division of South Africa is the contrast between Alexandra Township on one side of the highway and Sandton on the other side. This is the case with many other South African cities and towns, consisting of a black 'locations' and predominantly white suburbs. Certainly the communities residing in the two places will not have the same experiences. Therefore they should also not be

Allan Boesak, Farewell to Innocence: A Socio-Ethical Study on Black Theology and Power. New York:

Orbis Books, 1986: xi.

Cf. Goba, i.

Cf. Bundy, C. Short-changed? South Africa since Apartheid. Auckland Park: Jacana, 2014:7.

6 RW Johnson. South Africa's Brave New World: The Beloved Country since the End of Apartheid. London:

Penguin Books, 2010:3. cf. B MacArthur. The Penguin Book of the Twentieth Century Speeches.

Suffolk: Penguin 1999:498.

7 Ben Turok. The Development of a Divided Country: Understanding the ANC Today. Auckland Park: Jacana, 2011a:1, cf. Sampie Terreblanche. A History of Inequality in South Africa. Pietermaritzburg: University of Natal Press, 2002:1.

8 In this article Black refers to all those who are not white and are not of European descent, and to those who are 'black Africans, 'coloured' and 'Indian people'. It refers to all those who bore the brunt of the brutalities of apartheid, and continue to suffer from the legacies bequeathed by apartheid and colonialism.

9 Buffel, 471.

10 Moeletsi Mbeki. Architects of Poverty: Why African Capitalism needs Changing. Johannesburg: Picador Africa, 2009:7.

11 Turok, 3. 
expected to engage in theological reflection in the same way. To expect poor blacks in Alexandra to engage in the same theological reflections and with the same results as the wealthy whites in Sandton is to do what was pointed out by Goba during the struggle for liberation: "Blacks are not expected to think critically nor for that matter to theologise". 12 Whatever theological reflection comes out of poor black townships must inevitably be born out of the black experience, out of the anguish and suffering of black people in townships, informal settlements and rural villages. Much as it was necessary to reflect theologically on what it meant to be black in a racist and oppressive country, there is need to reflect theologically on what it means to be poor in the context of the poverty that continues to cause untold suffering and continues to wreak havoc in the lives of mainly blacks. The context of the majority of blacks is still that of "the struggle against the system". ${ }^{13}$ This makes the understanding of Black Theology provided by Boesak still to be valid: 'Black Theology is the theological reflection of black Christians on the situation in which they live'. ${ }^{14}$ Maimela also insists that Black Theology owes its origin to the unique experience of the people of colour, especially of African descent, in North America and South Africa, where people's blackness was enough justification for their pain, degradation, exploitation and oppression. $^{15}$

Boesak continues: "Blacks ask: What does it mean to believe in Jesus Christ when one is black?"16 Mofokeng asked the same question in a slightly different way: "How can faith in Jesus empower black people who are involved in the struggle for their liberation?"17 They were writing in the context of a South Africa that was then proudly racist and was resisting all efforts to move away from white racism. That context was marked by 'poor social relations, oppressive political system and very exploitative mode of economic production'. ${ }^{18}$ Massive resources were made available to defend racism and the associated system. People who resisted were tortured, detained and killed for opposing racism and the exploitative system. Black Theology can be understood as a theological reflection on the situation of poverty, which causes suffering and pain in the lives of millions of South Africans, the majority of whom are black ${ }^{19}$. It can be understood as a theological reflection in the context of a 'dream deferred' as economic liberation becomes a mere illusion for millions of blacks in townships, informal settlements and in rural villages.

\section{What then is Black Theology?}

Maimela defines Black Theology as a conscious, systematic, theological reflection on black experience, characterised by oppression, humiliation and suffering in white racist societies in North America and South Africa. ${ }^{20}$ This reflection is done in the light of scriptural witness. $^{21}$ Mofokeng points out that Black Theology "started as solely a theological

\footnotetext{
12 Goba, 2.

13 Takatso Mofokeng, "Human values beyond the market society" in Journal of Theology in Southern Africa, No. 76, 1991, 65.

14 Boesak, 1.

15 Simon Maimela, Black Theology, in Initiation to Theology: The Rich Variety of Theology and Hermeneutics edited by S Maimela and A König. Pretoria: Van Schaik, 1998:111-119.

16 Boesak, 1.

17 Takatso Mofokeng, The Crucified among the Cross Bearers: Towards a Black Christology. Kampen: Uitgeversmaatschappij JH Kok, 1983:1.

18 Mofokeng, 65.

19 Buffel, 473.

20 Maimela, 112.

21 Mofokeng, 1.
} 
reflection on the situation of oppression and exploitation in the light of the Gospel". ${ }^{22}$ However, the growth and development of this systematic, theological reflection as an academic discourse has been stifled somewhat in South Africa, and this has led to a lull in the writings on Black Theology. Some have even begun to announce the death of Black Theology and to write its obituary prematurely. It keeps on rising from the ashes and making an appearance that is unwelcome in some circles.

As a result Black theology continues to be stuck in two stages, namely: ${ }^{23}$

- the polemic (and definitional) phase and

- quasi-academic phase

Black theologians are often called upon to explain themselves, to define and defend Black Theology. As a result the discourse seems to be stuck on mainly offering definitions, and defending itself. Motlhabi decries the fact that the South African writings on Black Theology have not been as outstanding as the American writings and that it has subsequently not outgrown the polemical and definitional stages. ${ }^{24}$ One is therefore forced to recap what Black Theology is all about ${ }^{25}$.

Cone defines Black Theology as "the theology of liberation" ${ }^{26}$ He extends this simple definition by stating that Christian theology is and should be about a theology of liberation. This understanding is echoed correctly by South African theologians such as Pityana, Boesak and Goba. ${ }^{27}$ According to Cone, Black Theology is a religious explication of the need of black people to define the scope and meaning of black existence in a white racist society. ${ }^{28}$ Theology must always be about liberation, and when it is not about liberation, it is not worth pursuing. ${ }^{29}$ Cone insists that any theology "ceases to be theology of the gospel when it fails to arise out of the community of the oppressed".${ }^{30}$ He dismisses any theology that is apathetic towards the liberation of the poor and the oppressed: "Theologically any analysis of the gospel which did not begin and end with God's liberation of the poor and oppressed is ipso facto unchristian." ${ }^{\prime 31}$ To black theologians any theology that is indifferent to the theme of liberation is not Christian. Goba adds other useful dimensions by defining Black Theology as a "critical theological reflection on the praxis of the Christian faith which participates in the on-going process of liberation within the life of the black Christian community". ${ }^{32}$ In Black Theology blacks are reflecting theologically about their faith as they engage meaningfully in the struggle of the black community. They attempt to come to terms theologically with their black situation, which is the situation of poverty and structural racism entrenched in the South African society. It was always in the minds of the

\footnotetext{
Mofokeng, 19.

Buffel, 472.

24 Mokgethi Motlhabi, The Historical Origin of Black Theology, in the Unquestionable Right to be Free, edited by I Mosala and B Tlhagale. Johannesburg: Skotaville, 1986:4.

26.

26 James Cone, A Black Theology of Liberation. Maryknoll: Orbis Books, 1987:11.cf. Buffel, 472.

27 Barney Pityana, What is Black Consciousness?, in Essays in Black Theology edited by M Motlhabi.

Braamfontein: University Christian Movement, 1972:42 cf. Boesak, 9, and cf. Goba, 60.

28 James Cone, Black Theology and Black Liberation, in Essays in Black Theology edited by M Motlhabi. Braamfontein: University Christian Movement, 1972:28-36.

29 Olehile Buffel, "Black Theology and the Black Masses: The Need of an Organic Relationship between Black Theology and the Masses". Scriptura No.105, 2010:470-480.

30 Cone, 1975, God of the Oppressed. Minneapolis: Seabury: 1975:1.cf. Buffel 2010:472.

31 Cone, vi. cf. Buffel, 472.

32 Goba, 2. cf. Buffel, 472.
} 
exponents of Black Theology that it had to be done not for the poor but together with and alongside the poor and oppressed. ${ }^{33}$ For that reason, Basil Moore sees Black Theology "as a theology of the oppressed, by the oppressed, for the liberation of the oppressed". "It is a way of thinking and acting by black Christians as they attempt to discover and confront the socio-economic and political and cultural implications of their faith. ${ }^{35}$ This is the point emphasised by Chikane and Tsele:

In our research/study we must bear in mind the resolution contained in the final statement of the seminar: that we develop together with the oppressed people of this country a Black Theology of liberation and this theology must emerge from within the struggle of the oppressed. $^{36}$

Chikane and Tsele correctly acknowledged that the remaining task of Black Theology had not been undertaken by the time of the 1984 conference. ${ }^{37}$ That task cannot be carried out alone by academics and intellectuals from ivory towers of universities without journeying alongside the poor and oppressed and ensuring that there is an organic relationship between black theologians and those who are in pain and suffering as a result of oppression, exploitation, racism, sexism, Afrophobia and poverty.

Black Theology is a theology of the people that must be liberated from academic books, from comfortable conference centres, seminaries and universities but unleashed into the streets where there is pain and suffering as a result of poverty and oppression. This is a theology that must be authenticated by the pain and suffering of the poor and oppressed ${ }^{38}$.

\section{The Dream of a 'Better Life for all' Deferred}

When South Africans elected a democratic government and Nelson Mandela became the first president of a democratic, non-racial country the hope of the poor and oppressed was that there would be a better life, not only for the few, the whites, the rich, the elites, the powerful, the politicians and 'tenderpreneurs ${ }^{39}$ but 'better life for all'. There was hope of a better life for all as correctly promised by politicians. ${ }^{40}$ Since 1994 the government has repeatedly emphasised its 'pro-poor' policy focus and its determination to bring about a 'better life for all'. ${ }^{11}$ Unfortunately promises of 'better life for all' have not yet materialised. The South African dream had failed to materialise, the dream had been deferred, as Mbeki stated in some of his speeches. Mbeki said: "We are faced with the danger of a mounting rage to which we must respond seriously". He said that he was haunted by the nightmare of a seething majority that would boil over into rebellion because its liberation had been deferred rather than redeemed. Mbeki asked the question in one of his speeches, paraphrasing a poem by Langston Hughes: 'What happens to a dream

\footnotetext{
3 Buffel, 473.

Basil Moore, The Challenge of Black Theology. Atlanta: John Knox Press, 1973:viii.cf. Buffel, 473.

Cf. Goba, 60.cf. Buffel, 473.

F Chikane and M Tsele, Conference report: Black Theology and the Black Struggle - Conference held at St Francis Xavier. Cape Town. Braamfontein: Institute of Contextual Theology, 1984:1. cf. Buffel, 473.

37 Chikane and Tsele, 1, Buffel, 473.

38 Buffel, 473.

39 'Tenderpreneur' is a new word that is used to refer to those well-connected comrades who use their political connectivity and brown envelopes to secure state tenders and enrich themselves. This is from a combination of two words, tender and entrepreneurs.

40 cf. Anthea Jeffery, Chasing the Rainbow: South Africa's Move from Mandela to Zuma. Johannesburg: South African Institute of Race Relations, 2010: xxv.

41 Jeffrey, 317.
} 
deferred?' It explodes. This captured the imagination of many but particularly the prolific author Mark Gevisser who wrote a biography of Mbeki with the title: The Dream deferred: Thabo Mbeki, who cites the poem: ${ }^{42}$

What happens to a dream deferred?

Does it dry up

Like a raisin in the sun?

Or fester like a sore-

And then run?

Does it stink like rotten meat?

Or crust and sugar over-

Like syrup sweet?

Maybe it just sags

Like a heavy load

Or it explodes ? $^{43}$

Hughes' concern was the plight of fellow black Americans whose dreams of emancipation had sagged, rotted and festered into city ghettoes such as Harlem ${ }^{44}$, just like the dream of the poor in townships such as Alexandra, Diepsloot, etc. Mbeki appropriated the poem to refer to the crisis of expectation of black South Africans awaiting liberation and who often found themselves with less than they had before, and were on the brink of a dangerous explosion. It was unintentionally prophetic, that Mbeki spoke about a dream deferred and exploding, when one looks at recent spates of service delivery protests in the last few years. According to Moeletsi Mbeki South Africa has one of the largest occurrences of social protest against incompetence and corruption at various levels of the political sector and this proves the fallacy that there can be no social and political upheavals in a democracy. ${ }^{45}$

The dream of a better life for all remains an illusion for millions of poor in townships, informal settlements and villages. Their dreams have become, in the words of Boesak, "the blanket of the rich; where justice for the poor is a line in a slogan but not the song of our hearts". ${ }^{46}$ As their dreams lie shattered the poor face the following challenges: starvation, nutrition-related illnesses, infant mortality, premature death, drastically reduced life expectancy, chronically reduced standards of living and devastating impact of the HIV and Aids pandemic, violence and corruption, etc. In a newspaper article Archbishop emeritus Desmond Tutu said this about the reality of millions of South Africans:

The fact is that too many South Africans continue to live in squalor. Too many babies continue to die from preventable diseases. Too many children go to school in the morning without proper nourishment. Too many adults who are breadwinners are unemployed. Too many South Africans are desperate and degraded, waiting for government to deliver the fruits of freedom while being exposed to a daily diet of allegations of corruption and maladministration ${ }^{47}$

\footnotetext{
Mark Gevisser, The Dream Deferred: Thabo Mbeki. Johannesburg: Jonathan Ball, 2007:1.

Gevisser, xxxi, cf. A Zegeye and J Maxed, Our Dream Deferred. Pretoria: Unisa, 2002:1.

Gevisser, xxxi.

Moeletsi Mbeki (ed.), Advocates for Change: How to Overcome Africa's Challenges. Johannesburg: Picador Africa, 2011:13.

Allan Boesak, Running with Horses: Reflections of an Accidental Politician. Cape Town: Joho Publications, 2009:1-2.

Desmond Tutu, Viva Patrice Motsepe, for your Gesture of Generosity, in City Press, 02/02/2002:31.
} 
It is important to note that the reality of a South African dream is contested by many people. It is contested amongst others by Moeletsi Mbeki, who said: "I don't think that there is a South African dream. I think there are different South African dreams; different dreams for different groups, classes and ethnic groups". ${ }^{48}$ However, the majority of the blacks who are poor are united in their dream of a better life for all which is consistent with promises made from time to time. It is that dream which has been deferred. Therefore, the theological reflections that happen in townships and rural villages should be the critical theological reflection in the light of a dream deferred.

\section{The Reality of a Divided Country and Divided Economy}

In the South African context the political kingdom has not yet been followed by the economic kingdom. According to Du Toit South Africa has successfully transformed its political environment but this has not been accompanied by an economic transformation. ${ }^{49}$ South Africa may be a liberated, democratic, non-racial country but it is like there are two countries, one white and one black. Twenty-two years after the creation of the new South Africa, the country is still divided into the white part and the black part. The Western world remains rich and the African world remains poor. A leading Afrikaner academic, Sampie Terreblanche points out this reality of two nations: "South Africa is indeed a country of two nations, one rich and the other poor". 50 The two nations are separated by a racial divide. The political and legal empowerment of blacks since 1994 has not yet automatically been translated into socio-economic empowerment, hence the continued existence of the two nations. ${ }^{51}$ It is a fact that the majority of those who are poor are black. The reality of a country that is still divided was also acknowledged by Thabo Mbeki who said at the occasion of his inauguration as President of the Republic of South Africa on 14 June 1999: "All of us are aware that our country continues to be divided along racial and other lines and is therefore much more difficult to unite around common objectives".52

It is not only the two nations that are divided but the economy is also divided. This is the dual economy (skyscraper economy) that is composed of extreme wealth on the one hand and extreme poverty on the other hand and continues to bear testimony to the existence of two nations. ${ }^{53}$ As an illustration of his point, Turok says: "As you fly in, you see the impressive tall buildings, and then you land and see spaza shops, hawkers in the street and masses of very poor people". ${ }^{54}$ The impressive tall buildings are in Sandton whereas the spaza shops, hawkers and masses of poor people are in Alexandra. There is this "dualism between the rich centre and the poor periphery" 55 Turok cites Thabo Mbeki who had said that there is a structural fault in the South African economy. ${ }^{56}$ This structural fault is signalled by the difference between the first economy and the second economy. Turok estimates that more than half the South African population live in the second economy. This is approximately 24 million people, 15 million in rural areas and 8 million in town-

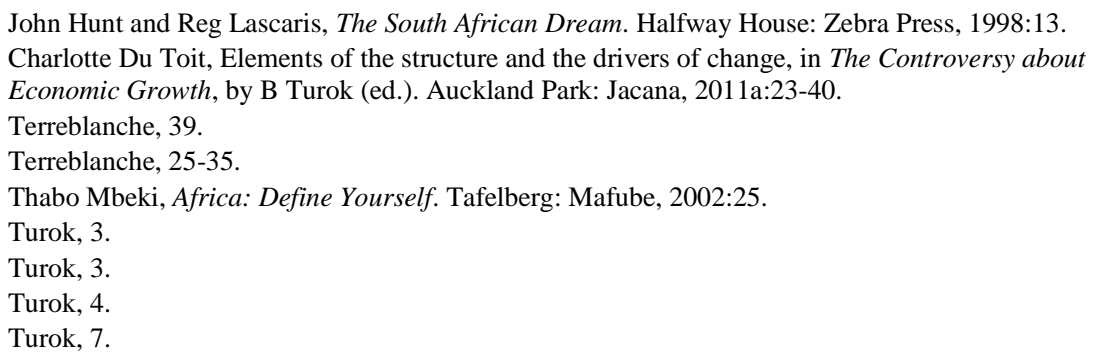


ships. Turok says: "For years I have been saying that the second economy consists of people living in the rural areas and the townships".

Turok argues that some forms of apartheid and its structures are still prevalent in society. He says:

In my view, the biggest problem in South Africa is the continuation of apartheid in some forms. We have abolished many laws and yet we still have dualism, we have a skyscraper economy; we have huge poverty and one of the highest levels of inequality in the world. ${ }^{58}$

The dual economy is characterised by poverty and associated pain and suffering. Poverty refers to a state of want or disadvantage, in that the poor are rendered by the system to be incapable of attaining minimal standards of living. ${ }^{59}$ Many researchers are agreed on more or less the following definition of poverty as: "The inability of individuals, households or entire communities to command sufficient resources to satisfy a socially acceptable minimum standard of living" ${ }^{60}$ This definition may not cover all aspects of poverty. However, it captures the essence of what poverty involves. Poverty is a multidimensional condition and developing a comprehensive description is a very complex undertaking that should include as many aspects as possible. ${ }^{61}$ Describing the extent of poverty, Pillay says in a foreword to a book edited by May:

In South Africa indications were that $50 \%$ of the population could be considered poor and that the gap between the rich and the poor was among the largest in the world. These high levels of poverty and inequality affect the living standards, economic growth and levels of crime and social stability. ${ }^{62}$

The majority of those who are poor are black, and reside in townships, informal settlements and rural areas. Socio-economic conditions in these predominantly black areas are very depressing and devastating. The poor are part of a vicious cycle of poverty from which it is difficult to escape. It is in those conditions where critical and relevant theological reflection is required.

The dual economy of South Africa is characterised by some unique poverty, in the sense that in contrast to other countries, which never had statutory discrimination, it is concentrated among the blacks. This is a legacy that has been inherited from the past, as Terreblanche says:

When in 1994, a democratically elected government came to power, it inherited a contradictory legacy; the most developed economy in Africa on the one hand, and major socio-economic problems on the other. ${ }^{63}$

Terreblanche acknowledges that it is mostly blacks who are at the receiving end of the socio-economic problems mentioned above. This is supported by former Archbishop of Cape Town, Archbishop Ndungane, who says that South Africa inherited from apartheid a

57 Turok, 7-8.

58 Turok, 9.

59 HM Ravnborg and Sano HO, The Poverty Objective in Development Assistance. Johannesburg:

Centre for Development Research, 1994:1.

60 Julian May, Poverty and Inequality in South Africa. Cape Town, David Phillip, 2000:5, cf. Julian May, Poverty and Inequality in South Africa: Report Prepared for the Office of the Executive Deputy President and the Inter-ministerial Committee on Poverty and Inequality. Durban: Praxis Publishing 2001:1, cf. Hennie Pieterse, Preaching in a context of Poverty. Pretoria: Unisa, 2001:30.

61 A Whiteford et al., A Profile of Poverty, Inequality and human development. Pretoria: HSRC, 199:1.

62 Julian May, Poverty and Inequality in South Africa, 2.

63 Terreblanche, 25. 
legacy of economic and social distress and dysfunctions. ${ }^{64}$ These are socio-economic and political structures in which poverty is entrenched, and that cannot be ignored in any theological reflection. Therefore, the poor are not poor because they are lazy or because there is something inherently wrong with them. They are poor because of this entrenchment of poverty in societal structures. According to Boff and Pixley, "The poor are poor because they are exploited or rejected by a perverse economic system. This is an exploitative and an excluding system which means that the system keeps them under it or outside it". ${ }^{65}$

South Africa has one of the highest levels of inequality in the world. ${ }^{66}$ In fact it is the highest as South Africa is believed to have overtaken Brazil as the country with the widest inequality gap. Makgetla states that recent data on the levels of inequality show that South Africa may have the worst inequitable distribution in the world, as Brazil has improved its position significantly in terms of its Gini coefficient. ${ }^{67}$ The Gini coefficient is most commonly used statistical calculation of inequality.

The distribution of wealth is extraordinarily unequal. While the consumerist-driven and affluent spend millions on houses (mansions), cars and imported luxury goods, a large proportion of South Africans remains without shelter, safe and reliable transport, and struggle to feed themselves and their families. ${ }^{68}$ According to Barberton et al. South Africa is still marked by poverty, inequality and unemployment. ${ }^{69}$

Makgetla says that low employment is associated with an inequitable distribution of income. ${ }^{70}$ This poverty and inequality lead to joblessness and suffering.

\section{The Economic Realities and the Prophetic Voice and Activism}

The above are economic realities which on the surface may appear only of academic importance, but which affect millions of the South African people as they survive and live in what Mbeki refers to as 'conditions of degrading poverty'. Mbeki has gone further to say:

Our nights cannot but be nights of nightmares while millions of our people live in conditions of degrading poverty. Sleep cannot come easily when children get disabled, both physically and mentally, because of lack of food. No night can be restful when millions have no jobs, and some are forced to beg, rob and murder to ensure that they and their own do not perish from hunger. ${ }^{71}$

These are the conditions that paint the black experience and must be taken into consideration as blacks engage in theological reflection. These are the conditions in which black theologians and clergy have to live out their prophetic activism. ${ }^{72}$ This is not much different from the time of apartheid when many of the clergy and theologians became the champions of the poor and oppressed. However, after the liberation that was ushered in by the democratic elections of 27 April 1994, the church, the clergy and theologians seem to

\footnotetext{
64 Njongonongkulu Ndungane, A World with a Human Face: A Voice from Africa. Cape Town: David Phillips, 2003:20 
have gone back to sleep. The release of political prisoners and detainees, the return of the exiles, the unbanning of some leaders, the scrapping of some apartheid legislation and other developments that led to political liberation in South Africa contributed to church leaders and the church in general taking a back seat with regard to prophetic activism. The church and its leadership seem to have withdrawn from the struggle. It is as if the political kingdom has been sought and found and everything else followed. It is as if they subscribe to the biblico-political dictum of Kwame Nkrumah that says: "Seek yee first the political kingdom". Dismissing the myth of the primacy of the political kingdom, Martey says: "We have painfully come to realise that the primacy in politics cannot solve Africa's acute social and economic problems in a world ruled and controlled by white supremacy". ${ }^{73}$

In contrast to the past it looks as if the prophetic voice and progressive church activism that used to be rife through such prophets such as Takatso Mofokeng, Desmond Tutu, Allan Boesak, Frank Chikane, Molefe Tsele, Sister Bernard Ncube and many others has come to an end. These prophets had strong organic relationships with the masses. They participated in community meetings, rallies and other events. They also led demonstrations and presided and preached at 'political funerals'. During sermons and speeches at funerals one would hear black liberation theology coming alive. In the words of Boesak black theology of liberation came alive "in front of countless audiences at meetings, rallies, marches, church services and ecumenical gatherings here and abroad". ${ }^{74}$ It is possible that every Sunday we have prophetic voices from pulpits of many churches. If that happens then preachers are preaching to the converted and this can hardly challenge the powers that be. If that happens then it means the people are not motivated to the extent that they are willing to live out their faith in public. If that happens it means that the prophetic voices have become blunt and cannot be heard. It is also possible that preachers are now encouraging the audiences to privatise religion and spiritualise the gospel message and keep politics out of the pulpit. If that happens it may mean that the church is no longer relevant in people's existential realities.

The role that black theologians and clergy played in the past enhanced the relevance of the church in a context of political repression, poverty and oppression. As they opposed apartheid and ministered to victims of apartheid they had strong organisational links with the masses and with organisations of the masses, as they held hands with masses and endured the teargas that was unleashed on the demonstrating masses and those who were grieving their deceased at funerals. The prophetic activists, clergy and theologians were fearless in the face of possibilities of detention, torture, banning orders, exile and even death. It is the prophetic role of these church leaders and theologians that helped in the process of articulating black theological reflection in the context of racism and oppression. Some of these prophets joined the civil service, some retired, some became managers of academic institutions and others joined BEE companies. The departure to different sectors robbed South Africa of its most articulate liberation theologians and public theologians who could appeal to people of all persuasions. Those who remained in the leadership of the different churches became silent and started focusing only on their congregational ministry unrelated to the plight of the poor and the oppressed. Many organisations, including the South African Council of Churches (SACC) which used to play a prophetic role, became weaker and lost their critical voices. There came a time during the history of the SACC when the sharp prophetic voice and ministry of the ecumenical body became somewhat

73 E Martey, African Theology: Inculturation and Liberation. Maryknoll: Orbis books, 1994:51.

74 Boesak, Running with Horses, 7. 
blunt, especially when it pursued a relationship of partnership with the governing party, the ANC. ${ }^{75}$

\section{Mofokeng's Proposal of Descending to the Deepest Level of the Social Matrix}

One cannot offer a blueprint or a template of black theological reflection as situations of the 'excruciating pain' of black experience are different. At best one can argue for the need not only always to bear in mind the painful experiences of the poor and the oppressed but to engage in analysis of socio-economic political conditions under which the people live. Mofokeng's challenge to pastors and theologians to engage in "a correlation between social analysis and theological reading of the Bible"76 must be taken seriously in theological reflection in the context of pain and suffering. This is what he refers to as a pre-theological stage. ${ }^{77}$ Mofokeng made this argument in view of critiquing the traditional way of going about the Bible that has become untenable. This traditional way presented theological reflection as simply to read, to know the gospel message and then believe its message and be saved. Mofokeng reiterated what has been proposed by other liberation theologians such as Cone, that is, a new hermeneutic, which today is no longer that new. To emphasise his point about a new and different hermeneutic, Mofokeng cites James Cone who said: "In this new situation it would be helpful to return to the concrete social reality of our existence, so that we may be permitted to move to a deeper theological level. I don't believe that we can experience the deeper level of our theological identity until we have immersed ourselves in the social matrix in which our identity must be actualised". ${ }^{78}$

Mofokeng challenges pastors and theologians to descend to the deepest level of the South African social matrix. They have to descend to the deepest socio-economic, political and religious dungeons where the overwhelming majority of black Christians are languishing "in order to capture not only the cry of the oppressed but also what Paul calls the groaning for the manifestation of the children of God". 79

This hermeneutic innovation is not only an imperative but it is also a Christological and pneumatological necessity, according to Mofokeng. ${ }^{80}$ To emphasise this point Mofokeng says:

It is a Christological necessity because the God of the Christian faith became the lowest of the oppressed and made indelibly deep footprints in the world in order for humankind never to negate and hate the world but to affirm it. God the Spirit descends to the deep socio-economic, political and religious Crossroads and Winterveldts of our world and creates a community that believes and confesses Jesus of Nazareth, the Christ, and pledged to follow him and his trail in the world. ${ }^{81}$

This is in line with what Paul says (in Philippians 4:6-8):

Who, being in very nature God, did not consider equality with God something to be grasped, but made himself nothing, taking the very nature of a servant, being made in

cf. Buffel, 475.

Mofokeng, Searching for the Gospel Message "Between the Times", 1.

Mofokeng, Searching for the Gospel Message "Between the Times", 1.

78 Takatso Mofokeng, Searching for the Gospel Message "Between the Times, in Journal of Theology in Southern Africa, Vol 16, Dec 1988:1, cf. James Cone, What is the Church? In Hammering Swords in to Ploughshares, edited by Buti Thagale and Itumeleng Mosala. Johannesburg: Skotaville, 1986:144. 
human likeness. And being found in appearance as a man, he humbled himself and became obedient to death - even death on the cross! (NIV).

If Jesus descended to the deepest level pastors and theologians cannot avoid descending to the deepest level of the South African social matrix where the majority of the South Africans are subjected to pain and suffering. It is in that situation where pastors and theologians have to journey with and alongside the poor, and together with them articulate a theology of liberation. It is only in that journey that pastors and theologians can "respond creatively to urgent existential and theological challenges of our time". 82 In this journey pastors and theologians have to determine priorities among a host of theological questions. They also have to develop sensitivity that enables them to capture the cry of the fellow oppressed blacks as it emerges from the situation of oppression and from a new praxis. ${ }^{83}$ This sensitivity can only be developed provided pastors and theologians have organic relationships with the suffering masses and their movements. ${ }^{84}$

\section{Conclusion}

It is important to note that the leaders referred to above were organically linked to organisations of the people in the form of churches, community based organisations and nongovernmental organisations that directly served the masses. There are many others who boarded the gravy train and left the masses to their own devices, to the extent that we can appropriate the question raised by MacMaster: Where have all the Pastors gone? ${ }^{85}$ These are the kinds of prophets that are now in short supply in the new South Africa in the arena of public theology and black liberation theology, who are desperately needed. Such leaders are needed to facilitate black theological reflection in the midst of pain and suffering amidst poverty. The main argument of this article is that we still need what black theologians of the past referred to as a "critical theological reflection on the praxis of the Christian faith which participates in the ongoing process of liberation within the life of the black Christian community". This is needed for as long as South Africa consists of the dual economy, the first and the second economy, respectively marked by extreme wealth and extreme poverty. This is needed for as long as blacks live mainly in townships, informal settlements and rural villages and the majority of whites in suburbs, notwithstanding a few blacks who have managed to climb the economic ladder and are now a tiny minority in white suburbs.

\section{BILIOGRAPHY}

Barberton, C, Blake, M and Kotze, H 1998. Creating Action Space: The Challenge of Poverty and Democracy in South Africa. Cape Town: Idasa.

Boesak, A 1988. Farewell to Innocence: A Socio-ethical Study on Black Theology and Black Power. New York: Orbis Books.

Boesak, A 2009. Running with Horses: Reflections of an Accidental Politician.

Cape Town: Joho Publications.

82 Mofokeng, Searching for the Gospel Message, 2.

83 Mofokeng, The Crucified Crossbearers, 18-19.

84 cf. Buffel, 475.

85 Llewellyn MacMaster, "Where have all the Pastors gone? A Case for Public Pastoral Care in a Democratic South Africa Experiencing Growth Pains". Journal of Theology in Southern Africa, Vol. 132, November 2008:3-15. 
Boff, C and Pixley, G 1989. The Bible, the Church and the Poor. Maryknoll: Orbis Books.

Buffel, O 2010. "Black Theology and the Black Masses: The Need of an Organic

Relationship between Black Theology and the Masses", in Scriptura,

No. 105:470-480.

Bundy, C 2014. Short-changed? South Africa since Apartheid. Auckland Park: Jacana.

Chikane, F. and Tsele, M. 1984. Conference Report: Black Theology and the Black

Struggle - Conference Held at St. Francis Xavier, Cape Town. Braamfontein:

Institute of Contextual Theology.

Cone, J 1972a. Black Theology and Black Liberation, in Essays in Black Theology

by M Motlhabi (ed.). Braamfontein: University Christian Movement, 42.

Cone, J 1975b. God of the Oppressed. Minneapolis: Seabury.

Cone, J 1986c. What is the Church? in Hammering Swords into Ploughshares, by

B Tlhagale and I Mosala (eds.). Johannesburg: Skotaville.

Cone, J 1987d. A Black Theology of Liberation. Maryknoll: Orbis Books.

Du Toit, C 2011. "Elements of the Structure and Drivers of Change", in The Controversy about Economic Growth, by B Turok (ed.). Auckland Park: Jacana.

Gevisser, M 2007. The Dream Deferred: Thabo Mbeki. Johannesburg: Jonathan Ball.

Goba, B 1986. An Agenda for Black Theology. Johannesburg: Skotaville.

Hunt, J and Lascaris, R 1998. The South African Dream. Halfway House: Zebra.

Jeffrey, A 2010. Chasing the Rainbow: South Africa's Move from Mandela to Zuma.

Johannesburg: South African Institute of Race Relations.

Johnson, RW 2010. South Africa's Brave New World: The Beloved Country since the End of Apartheid. London: Penguin Books.

MacArthur, B 1999. The Penguin Book of the Twentieth Century Speeches.

Suffolk: Penguin.

MacMaster, L 2008. "Where have all the Pastors gone?" In Journal of Theology in Southern Africa, Nov Vol 132:3-15.

Maimela, SS 1998. "Black Theology", in Invitation to Theology: The rich variety of

Theology and Hermeneutics by S. Maimela and A König (eds.). Pretoria:

Van Schaik, 111-119.

Makgetla, N 2011. "Essence of the inherited Structure", in The Controversy about

Economic Growth by B Turok (ed.), Auckland Park: Jacana/DBSA.

Martey, E 1994. African Theology: Inculturation and Liberation. Maryknoll: Orbis Books.

Mbeki, M 2009. Architects of Poverty: Why African Capitalism Needs Changing.

Johannesburg: Picador.

May J 2000. Poverty and Inequality in South Africa. Cape Town: David Phillip.

May, J 2001. Poverty and Inequality in South Africa: Report Prepared for the Office of the

Deputy President and the Inter-ministerial Committee on Poverty and Inequality.

Durban: Praxis Publishing.

Mbeki, T 2002. Africa: Define Yourself. Tafelberg: Mafube.

Mofokeng, T 1983. The Crucified Among the Cross Bearers: Towards a Black Christology.

Kampen: Uitgeversmaatschappij, JH Kok.

Mofokeng, T 1988. "Searching for the Gospel Message 'between Times"”, in Journal of

Theology in South Africa, Vol 16, Dec:1-9.

Mofokeng, T 1991. "Human Values beyond the Market Value", in Journal of Theology in

Southern Africa, No. 76. 
More, B 1973. The Challenge of Black Theology. Atlanta: John Knox.

Motlhabi, M 1986. "The Historical Origin of Black Theology", in The Unquestionable

Right to be Free by I Mosala and B Tlhagale (eds.). Johannesburg: Skotaville, 4.

Ndungane, N 2003. A World with a Human Face: A Voice from Africa. Cape Town:

David Phillip.

Pieterse, HJC 2001. Preaching in a Context of Poverty. Pretoria: Unisa Press.

Pityana, B 1972. "What is Black Consciousness?" In Essays in Black Theology by

M Motlhabi (ed.). Braamfontein: University Christian Movement.

Ravnborg, HM and Sano, HO 1994. The Poverty Objective in Development Assistance.

Johannesburg: Centre for Development Research.

Terreblanche, S 2002. A History of South Africa. Pietermaritzburg: University of

Natal Press.

Turok, B 2011a. The Development of a Divided Country: Understanding the ANC Today. Auckland Park: Jacana.

Tutu, D 2002.Viva Patrice Motsepe, for your Gesture of Generosity, in City Press, 02/02/2002:31.

Whiteford, A, Posel, D and Kelatwang T 1995. A Profile of Poverty, Inequality and Economic Growth. Pretoria: HSRC. 